\title{
Selective Oxidation of Hydrogen Sulfide Containing Excess Water and Ammonia over Bi-V-Sb-O Catalysts
}

\author{
Dae-Won Park ${ }^{\dagger}$ Byung-Ha Hwang, Wol-Don Ju, Moon-Il Kim, Kyung-Hoon Kim and Hee-Chul Woo* \\ Department of Chemical Engineering, Pusan National University, Busan 609-735, Korea \\ *Department of Chemical Engineering, Pukyung National University, Busan 608-739, Korea \\ (Received 1 September 2004 - accepted 28 December 2004)
}

\begin{abstract}
We investigated the selective oxidation of hydrogen sulfide to elemental sulfur and ammonium thiosulfate by using $\mathrm{Bi}_{4} \mathrm{~V}_{2-x} \mathrm{Sb}_{x} \mathrm{O}_{11-y}$ catalysts. The catalysts were prepared by the calcination of a homogeneous mixture of $\mathrm{Bi}_{2} \mathrm{O}_{3}$, $\mathrm{V}_{2} \mathrm{O}_{5}$, and $\mathrm{Sb}_{2} \mathrm{O}_{3}$ obtained by ball-milling adequate amounts of the three oxides. The main phases detected by XRD analysis were $\mathrm{Bi}_{4} \mathrm{~V}_{2} \mathrm{O}_{11}, \mathrm{Bi}_{1.33} \mathrm{~V}_{2} \mathrm{O}_{6}, \mathrm{BiSbO}_{4}$ and $\mathrm{BiVO}_{4}$. They showed good $\mathrm{H}_{2} \mathrm{~S}$ conversion with less than $2 \%$ of $\mathrm{SO}_{2}$ selectivity with a feed composition of $\mathrm{H}_{2} \mathrm{~S}_{2} \mathrm{O}_{2} / \mathrm{NH}_{3} / \mathrm{H}_{2} \mathrm{O} / \mathrm{He}=5 / 2.5 / 5 / 60 / 27.5$ and $\mathrm{GHSV}=12,000 \mathrm{~h}^{-1}$ in the temperature ranges of $220-260{ }^{\circ} \mathrm{C}$. The highest $\mathrm{H}_{2} \mathrm{~S}$ conversion was obtained for $\mathrm{x}=0.2$ in $\mathrm{Bi}_{4} \mathrm{~V}_{2-x} \mathrm{Sb}_{x} \mathrm{O}_{11-y}$ catalyst. TPR/TPO results showed that this catalyst had the highest amount of oxygen consumption. XPS analysis before and after reaction confirmed the least reduction of vanadium oxide phase for this catalyst during the reaction. It means that the catalyst with $\mathrm{x}=0.2$ had the highest reoxidation capacity among the $\mathrm{Bi}_{4} \mathrm{~V}_{2-x} \mathrm{Sb}_{x} \mathrm{O}_{11-y}$ catalysts.
\end{abstract}

Key words: Hydrogen Sulfide, Selective Oxidation, Ammonium Thiosulfate, $\mathrm{Bi}_{4} \mathrm{~V}_{2-x} \mathrm{Sb}_{x} \mathrm{O}_{11-y}$

\section{INTRODUCTION}

In petroleum refineries and natural gas plants, hydrogen sulfide $\left(\mathrm{H}_{2} \mathrm{~S}\right)$ is typically collected by contact with amine-based solutions, and subsequently fed to a well known Claus plant [Goar, 1975; Lell, 1985]. However, total recovery of sulfur through the Claus process is not possible, due to limitations of thermodynamic equilibrium. As the environmental regulations become more stringent, it is necessary to further treat the residual (tail) gas of the Claus plants. $\mathrm{H}_{2} \mathrm{~S}$ in the tail gas of Claus plants or from other emission sources has been conventionally treated by various techniques such as adsorption, absorption, and wet oxidation.

Recently, a dry catalytic process has been developed for the selective catalytic oxidation of $\mathrm{H}_{2} \mathrm{~S}$ to elemental sulfur. Examples of commercially developed catalysts for this purpose are the titaniumbased catalysts in the MODOP process [Kettner and Liermann, 1983, 1988] and the iron-based catalysts in the Super Claus process [van den Brink and Geus, 1994; van Nisselrooy and Lagas, 1993]. Vanadium-based mixed oxides [Li et al., 1996, 1997] and NaX-WO $\mathrm{W}_{3}$ mixtures [Pi et al., 2004] were also used as catalysts for the selective oxidation of $\mathrm{H}_{2} \mathrm{~S}$ to elemental sulfur.

Hydrogen sulfide in the coke oven gas released from the steel smelting process is scrubbed and concentrated using aqueous ammonia solution. Concentrated $\mathrm{H}_{2} \mathrm{~S}$ that is separated from aqueous ammonia is transferred to the Claus plant to convert it into elemental sulfur, and remaining aqueous ammonia is usually incinerated. In this case, the control of $\mathrm{SO}_{x}$ emission is difficult because the stream contains not only excess water vapor but also a high concentration of ammonia.

One approach to resolving the problem is the selective catalytic oxidation of $\mathrm{H}_{2} \mathrm{~S}$ to ammonium thiosulfate (ATS) and elemental

\footnotetext{
To whom correspondence should be addressed.
}

E-mail: dwpark@pusan.ac.kr sulfur as reported in our previous works [Park et al., 1998, 1999; Cho et al., 2002; Kim et al., 2004]. We reported a new vapor phase catalytic process for the selective conversion of $\mathrm{H}_{2} \mathrm{~S}$ in a stream containing both ammonia and water. $\mathrm{V}_{2} \mathrm{O}_{5} / \mathrm{SiO}_{2}, \mathrm{Fe}_{2} \mathrm{O}_{3} / \mathrm{SiO}_{2}$ and $\mathrm{Co}_{3} \mathrm{O}_{4} /$ $\mathrm{SiO}_{2}$ catalysts showed good catalytic activities in the selective oxidation of $\mathrm{H}_{2} \mathrm{~S}$ to ATS and sulfur [Chun et al., 1997]. We reported improved performance of $\mathrm{V}-\mathrm{Sb}-\mathrm{O} / \mathrm{TiO}_{2}$ compared to $\mathrm{V}_{2} \mathrm{O}_{5} / \mathrm{TiO}_{2}$ in the selective oxidation of $\mathrm{H}_{2} \mathrm{~S}$ to ATS and sulfur [Park et al., 2002].

It is well known that $\mathrm{Bi}_{2} \mathrm{O}_{3}$ exhibits a remarkable range of useful solid-state properties [Sammes et al., 1999]. Many multicomponent systems containing ternary oxides of $\mathrm{Bi}$, such as bismuth vanadium molybdenum oxides (for example, $\mathrm{BiMo}_{1-x} \mathrm{~V}_{x} \mathrm{O}_{4}$ ) or bismuth vanadium oxide $\left(\mathrm{Bi}_{4} \mathrm{~V}_{2} \mathrm{O}_{11}\right)$, are efficient selective oxidation catalysts for hydrocarbons [Aghabozorg et al., 1997]. Structural oxygen is released from the catalyst, thereby converting it to a nonstoichiometric solid. The anion deficiency is recovered when gaseous oxygen is taken up by the catalyst, in a Mars-van Krevelen mechanism [Pomonis et al., 1981].

The conventional processes for the production of ATS are based on the liquid phase reactions. The ATS Claus tail gas clean-up process [Zey et al., 1980] is divided into two sections: absorption of $\mathrm{SO}_{2}$ from incinerator in aqueous ammonia and conversion of the intermediate product to ATS by sparging $\mathrm{H}_{2} \mathrm{~S}$ into the converter. In another ATS process [Benito, 1986], sulfuric acid is reacted with aqueous ammonia solution below $45^{\circ} \mathrm{C}$, then the mixture is contacted with $\mathrm{H}_{2} \mathrm{~S}$ to form ATS. Therefore, our process has the advantage of direct vapor phase operation compared to the above two processes.

In the current work, we further examined the performance of $\mathrm{Bi}_{4}$ $\mathrm{V}_{2-x} \mathrm{Sb}_{x} \mathrm{O}_{11-y}$ compounds for the selective oxidation of $\mathrm{H}_{2} \mathrm{~S}$ in the stream containing both ammonia and water. Solid-state modifications of the mixtures during the catalytic reaction tests were verified by characterization before and after the test by XRD and XPS. Temperature-programmed techniques (TPR and TPO) were also 
used to elucidate the redox properties of this catalyst system.

\section{EXPERIMENTAL}

\section{Preparation of Catalysts}

$\mathrm{Bi}-\mathrm{V}-\mathrm{Sb}-\mathrm{O}$ catalysts of nominal formula $\mathrm{Bi}_{4} \mathrm{~V}_{2-x} \mathrm{Sb}_{x} \mathrm{O}_{11-y}$, with $\mathrm{x}=0.2,0.5,1.0$, and 1.7 , were prepared following the procedure described previously [Aghabozorg et al., 1997]. The synthesis consisted in the calcination in air at $800{ }^{\circ} \mathrm{C}$ for $18 \mathrm{~h}$ of a homogeneous mixture of $\mathrm{Bi}_{2} \mathrm{O}_{3}$ (Aldrich, 99.9\%), $\mathrm{V}_{2} \mathrm{O}_{5}$ (Aldrich, 99\%) and $\mathrm{Sb}_{2} \mathrm{O}_{3}$ (Merck, analytical purity) obtained by ball-milling adequate stoichiometric amounts of the three oxides together.

\section{Catalytic Activity Measurement}

Reaction tests were carried out in a continuous flow fixed-bed reactor. The reactor was made of a Pyrex ${ }^{\circledR}$ tube with an i.d. of 0.0254 $\mathrm{m}$. A condenser was attached at the effluent side of the reactor, and its temperature was held at $110^{\circ} \mathrm{C}$ to condense only solid products (sulfur+ammonium thiosulfate). A line filter was installed after the condenser to trap any solid mist which had not been captured by the condenser. From the condenser up to the gas chromatograph, all the lines and fittings were heated above $120^{\circ} \mathrm{C}$ to prevent condensation of water vapor. The flow rates of gases were controlled by a mass flow controller (Brooks MFC 5850E). Water vapor was introduced to the reactant stream by using an evaporator filled with small glass beads, and its amount was controlled by a syringe pump.

The content of the effluent gas $\left(\mathrm{H}_{2} \mathrm{~S}, \mathrm{SO}_{2}\right.$, and $\left.\mathrm{NH}_{3}\right)$ was analyzed by a gas chromatograph (HP 5890) equipped with a thermal conductivity detector and a $1.83 \mathrm{~m}$ Porapak T column (80-100 mesh) at $100{ }^{\circ} \mathrm{C}$. The exit gas from the analyzer was passed through a trap containing a concentrated $\mathrm{NaOH}$ solution and vented out to a hood. The solid products (ATS and sulfur) were dissolved in distilled water to separate them, and were weighed individually after drying in vacuum oven at $110{ }^{\circ} \mathrm{C}$. The conversion of $\mathrm{H}_{2} \mathrm{~S}(\mathrm{X})$ and the selectivity to a special product $\left(\mathrm{SO}_{2}, \mathrm{~S}, \mathrm{ATS}\right)(\mathrm{S})$ are defined as follows:

$$
\begin{aligned}
& \mathrm{X}(\%)=\frac{\left[\mathrm{H}_{2} \mathrm{~S}\right]_{\text {inlet }}-\left[\mathrm{H}_{2} \mathrm{~S}\right]_{\text {oultet }}}{\left[\mathrm{H}_{2} \mathrm{~S}\right]_{\text {inlet }}} \times 100 \\
& \mathrm{~S}(\%)=\frac{[\text { Product }]_{\text {outlet }}}{\left[\mathrm{H}_{2} \mathrm{~S}\right]_{\text {inlet }}-\left[\mathrm{H}_{2} \mathrm{~S}\right]_{\text {outlet }}} \times 100
\end{aligned}
$$

For the calculation of ATS selectivity, moles of ATS was multiplied by a factor of 2 because 1 mol of ATS can be obtained from 2 mol of $\mathrm{H}_{2} \mathrm{~S}$.

\section{Characterization}

The surface areas of the catalysts were measured by $\mathrm{N}_{2}$ adsorption method using the BET technique (Micromeritics ASAP 2000). The phase analysis was performed by X-ray diffraction crystallography with $\mathrm{Cu} \mathrm{K} \alpha$ radiation (Rigaku, DMAX 2400). The $2 \theta$ range between $5^{\circ}$ and $90^{\circ}$ was scanned at a rate of $2^{\circ} / \mathrm{min}$. Identification of the phases was carried out by using JCPDS database. XPS analyses were performed with an X-ray photoelectron spectrometer (VG, ESCALAB 220) with monochromatic $\mathrm{Al} \mathrm{K} \alpha$ radiation. The samples were pressed into self-supporting wafers without any binder followed by a pretreatment at an ultrahigh vacuum. The binding energies were calculated by using the $\mathrm{C} 1 \mathrm{~s}$ band as reference (284.6 $\mathrm{eV}$ ). To investigate the phase cooperation mechanism, TPR was performed. Before reduction, samples were pretreated by heating under air flow from 25 to $450^{\circ} \mathrm{C}$ at a heating rate of $10^{\circ} \mathrm{C} / \mathrm{min}$. Re- duction was achieved under an $\mathrm{H}_{2} / \mathrm{N}_{2}$ gas mixture $\left(10\right.$ vol\% $\left.\mathrm{H}_{2}\right)$. Gas flow was $20 \mathrm{ml} / \mathrm{min}$ and temperature program was from 25 to $700{ }^{\circ} \mathrm{C}$ at a heating rate of $10^{\circ} \mathrm{C} / \mathrm{min}$. The amount of consumed $\mathrm{H}_{2}$ was detected by mass spectroscopy (VG Quadrupole). After the TPR experiment, the same sample was instantly tested in TPO under 2.5 vol $\% \mathrm{O}_{2}$ with helium gas balance.

\section{RESULTS AND DISCUSSION}

\section{Characterization of Catalysts}

Powder XRD patterns for various values of the antimony doping level, $\mathrm{x}$, are shown in Fig. 1 . For samples with $\mathrm{x}=0.2$ and $\mathrm{x}=$ 0.5 , the main peak corresponds to $\mathrm{Bi}_{4} \mathrm{~V}_{2} \mathrm{O}_{11}$. Small peaks of $\mathrm{BiVO}_{4}$ phase was also observed for these catalysts. For samples with $\mathrm{x} \geq$ 1.0 some characteristic peaks of $\mathrm{BiSbO}_{4}$ and $\mathrm{Bi}_{1.33} \mathrm{~V}_{2} \mathrm{O}_{6}$ were detected. $\mathrm{Bi}_{2} \mathrm{O}_{3}$ was also observed for the catalysts with $\mathrm{x}=1$.7. As might be expected from the high annealing temperatures used to synthesize these catalysts, all the samples were highly crystalline, as evidenced by the narrow reflections observed in XRD. The above-found phases were also reported to exist in the $\mathrm{Bi}-\mathrm{V}-\mathrm{Sb}-\mathrm{O}$ catalysts of Gaigneaux et al. [2001].

Table 1 shows BET surface area for the $\mathrm{Bi}_{4} \mathrm{~V}_{2-x} \mathrm{Sb}_{x} \mathrm{O}_{11-y}$ cata-

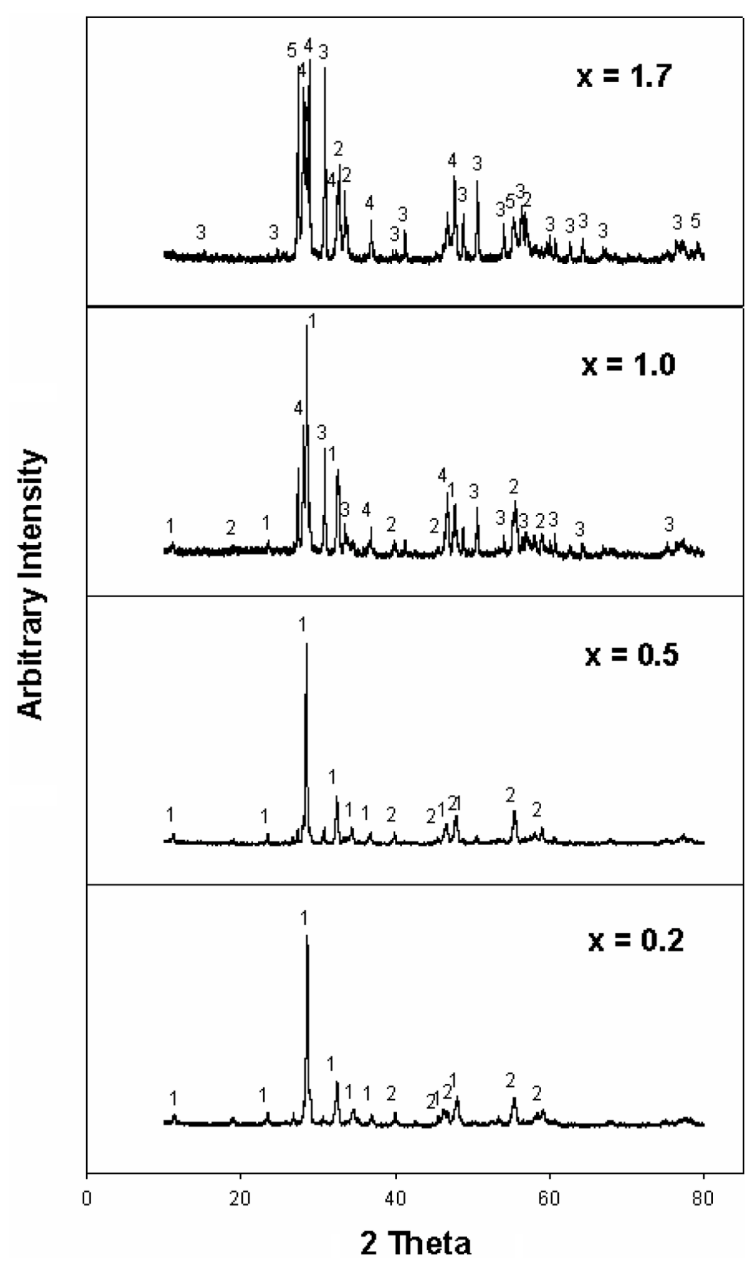

Fig. 1. Powder XRD patterns recorded for the $\mathrm{Bi}_{4} \mathrm{~V}_{2-x} \mathrm{Sb}_{x} \mathrm{O}_{11-y}$ catalysts (1: $\mathrm{Bi}_{4} \mathrm{~V}_{2} \mathrm{O}_{11}, 2: \mathrm{BiVO}_{4}, 3: \mathrm{BiSbO}_{4}, 4: \mathrm{Bi}_{1.33} \mathrm{~V}_{2} \mathrm{O}_{6}, 5$ : $\left.\mathrm{Bi}_{2} \mathrm{O}_{3}\right)$. 
Table 1. BET surface areas for $\mathrm{Bi}_{4} \mathrm{~V}_{2-x} \mathrm{Sb}_{x} \mathrm{O}_{11-y}$ catalysts

\begin{tabular}{lcccc}
\hline \hline \multirow{2}{*}{$\mathrm{Bi}_{4} \mathrm{~V}_{2-x} \mathrm{Sb}_{x} \mathrm{O}_{11-y}$} & \multicolumn{4}{c}{ BET surface area $\left(\mathrm{m}^{2} / \mathrm{g}\right)$} \\
\cline { 2 - 5 } & $\mathrm{x}=0.2$ & $\mathrm{x}=0.5$ & $\mathrm{x}=1.0$ & $\mathrm{x}=1.7$ \\
\hline Before reaction & 0.53 & 0.58 & 0.62 & 0.63 \\
After reaction & 0.18 & 0.12 & 0.27 & 0.35 \\
\hline
\end{tabular}

Table 2. Bulk nominal and experimentally determined surface concentration ratios for $\mathrm{Bi}_{4} \mathrm{~V}_{2-x} \mathrm{Sb}_{x} \mathrm{O}_{11-y}$ catalysts

\begin{tabular}{|c|c|c|c|c|c|c|}
\hline \multirow{2}{*}{$\begin{array}{c}\text { Catalyst } \\
\left(\mathrm{Bi}_{4} \mathrm{~V}_{2-x} \mathrm{Sb}_{x} \mathrm{O}_{11-y}\right)\end{array}$} & \multicolumn{2}{|c|}{ 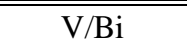 } & \multicolumn{2}{|c|}{$\mathrm{Sb} / \mathrm{Bi}$} & \multicolumn{2}{|c|}{$\mathrm{Sb} / \mathrm{V}$} \\
\hline & Bulk & XPS & Bulk & XPS & Bulk & XPS \\
\hline Fresh $(x=0.2)$ & 0.450 & 0.258 & 0.050 & 0.049 & 0.110 & 0.129 \\
\hline Used $(x=0.2)$ & 0.450 & 0.265 & 0.050 & 0.070 & 0.110 & 0.173 \\
\hline Fresh $(x=0.5)$ & 0.375 & 0.247 & 0.125 & 0.089 & 0.330 & 0.229 \\
\hline Used $(x=0.5)$ & 0.375 & 0.147 & 0.125 & 0.085 & 0.330 & 0.351 \\
\hline Fresh $(\mathrm{x}=1.0)$ & 0.250 & 0.120 & 0.250 & 0.101 & 1.0 & 0.453 \\
\hline Used $(\mathrm{x}=1.0)$ & 0.250 & 0.136 & 0.250 & 0.210 & 1.0 & 0.629 \\
\hline Fresh $(x=1.7)$ & 0.075 & 0.066 & 0.425 & 0.232 & 5.67 & 0.811 \\
\hline Used $(x=1.7)$ & 0.075 & 0.083 & 0.425 & 0.374 & 5.67 & 0.868 \\
\hline
\end{tabular}

lysts before and after reaction with a feed composition of $\mathrm{H}_{2} \mathrm{~S}_{2} \mathrm{O}_{2} /$ $\mathrm{NH}_{3} / \mathrm{H}_{2} \mathrm{O} / \mathrm{He}=5 / 2.5 / 5 / 60 / 27.5$ and $\mathrm{GHSV}=12,000 \mathrm{~h}^{-1}$ at $260{ }^{\circ} \mathrm{C}$ for $6 \mathrm{~h}$. The surface areas were much lower than in a normal working catalyst material, typically in the range of $0.12-0.63 \mathrm{~m}^{2} / \mathrm{g}$. The used catalysts showed smaller surface area than the fresh catalysts probably due to the agglomeration of catalyst particle or the deposition of some sulfur on the catalyst surface during the reaction.

The surface chemical composition of the samples was checked by performing XPS over a range of binding energies. An experiment was carried out before and after performing the catalytic reaction on the catalysts. The $\mathrm{O}$ 1s peak overlaps the region in which

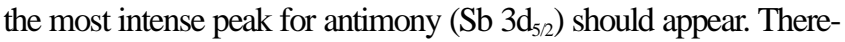
fore, the presence of antimony on the surface of samples should be probed by the $\mathrm{Sb} 3 \mathrm{~d}_{3 / 2}$ peak. In addition, concerning vanadium, only the $\mathrm{V} 2 \mathrm{p}_{3 / 2}$ component can be accurately treated because the $\mathrm{V} 2 \mathrm{p}_{1 / 2}$ peak overlaps with the $\mathrm{O} 1 \mathrm{~s}$ satellite peak.

Table 2 shows the surface chemical compositions of the catalysts before and after reaction test. The bulk chemical compositions, calculated from the amount of $\mathrm{Bi}_{2} \mathrm{O}_{3}, \mathrm{~V}_{2} \mathrm{O}_{5}$, and $\mathrm{Sb}_{2} \mathrm{O}_{3}$ used for the preparation of catalysts, are also included in this table. Surface concentration ratios of $\mathrm{V} / \mathrm{Bi}$ and $\mathrm{Sb} / \mathrm{Bi}$ determined by XPS are smaller than their bulk concentration ratios. The $\mathrm{Sb} / \mathrm{V}$ ratio on the surface of the fresh catalyst with $\mathrm{x}=0.2$ was 0.129 , higher than that in the bulk value of this compound, 0.110. Aghabozorg et al. [1977] reported that this trend was more evident for lower antimony doping level. However, this trend was inverse for the catalysts with $\mathrm{x} \geq 0.5$. In addition, the XPS results of $\mathrm{Sb} / \mathrm{V}$ ratio also show that the proportion of antimony after performing the catalytic reaction increases on the surface of catalysts. This may indicate a possible reconstruction of the surface of nominally orthorhombic samples to tetragonal during the catalytic reaction [Aghabozorg et al., 1977].

\section{Catalytic Activity}

Fig. 2 shows time variant conversion of $\mathrm{H}_{2} \mathrm{~S}\left(\mathrm{X}-\mathrm{H}_{2} \mathrm{~S}\right)$ and selectivity to $\mathrm{SO}_{2}\left(\mathrm{~S}_{-} \mathrm{SO}_{2}\right)$ for $\mathrm{Bi}_{4} \mathrm{~V}_{2-x} \mathrm{Sb}_{x} \mathrm{O}_{11-y}$ catalysts with a reactant composition of $5 \mathrm{vol} \% \mathrm{H}_{2} \mathrm{~S}, 2.5 \mathrm{vol} \% \mathrm{O}_{2}, 5 \mathrm{vol} \%, \mathrm{NH}_{3}, 60 \mathrm{vol} \%$

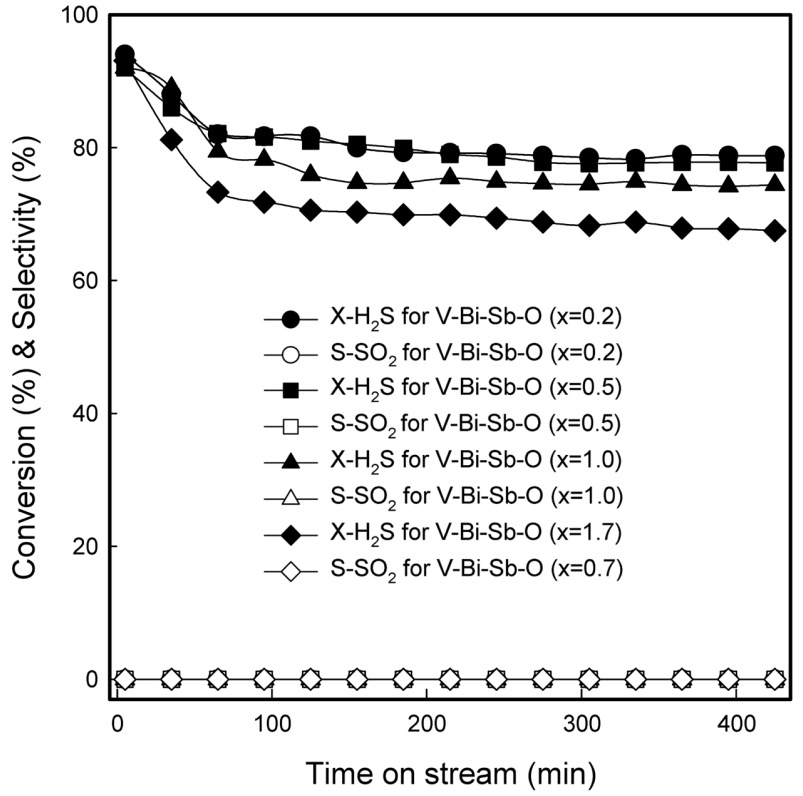

Fig. 2. Time variant conversion of $\mathrm{H}_{2} \mathrm{~S}$ and selectivity to $\mathrm{SO}_{2}$ for $\mathrm{Bi}_{4} \mathrm{~V}_{2-x} \mathrm{Sb}_{x} \mathrm{O}_{11-y}$ catalysts at $260{ }^{\circ} \mathrm{C}\left(\mathrm{H}_{2} \mathrm{~S} / \mathrm{O}_{2} / \mathrm{NH}_{3} / \mathrm{H}_{2} \mathrm{O} / \mathrm{He}=5 /\right.$ 2.5/5/60/27.5, GHSV $\left.=12,000 \mathrm{~h}^{-1}\right)$.

$\mathrm{H}_{2} \mathrm{O}$ and the balance helium at $260{ }^{\circ} \mathrm{C}$ with GHSV of $12,000 \mathrm{~h}^{-1}$. The catalyst with $\mathrm{x}=0.2$ showed the highest conversion of $\mathrm{H}_{2} \mathrm{~S}$. All the catalysts showed very low formation of $\mathrm{SO}_{2}$. They maintained stable activities after about 5 hours of reaction time. However, a considerable decrease of $\mathrm{H}_{2} \mathrm{~S}$ conversion was observed up to about 1-1.5 h. In our previous study [Shin et al., 2000], when a feed containing $1 \mathrm{vol} \%$ of $\mathrm{H}_{2} \mathrm{~S}$ only (the balance helium, without oxygen) was passed over fresh pure $\mathrm{V}_{2} \mathrm{O}_{5}$, complete conversion of $\mathrm{H}_{2} \mathrm{~S}$ was achieved initially and the fresh $\mathrm{V}_{2} \mathrm{O}_{5}$ produced only complete oxidation product, $\mathrm{SO}_{2}$. The result indicated that an oxidized form of vanadium having very active surface oxygen produced $\mathrm{SO}_{2}$, and only less labile lattice oxygen in partially reduced vanadium oxides could produce elemental sulfur via redox mechanism.

Table 3 summarizes the $\mathrm{H}_{2} \mathrm{~S}$ conversion and selectivities to $\mathrm{SO}_{2}, \mathrm{~S}$ and ATS for $\mathrm{Bi}_{4} \mathrm{~V}_{2-x} \mathrm{Sb}_{x} \mathrm{O}_{11-y}$ catalysts after $8 \mathrm{~h}$ reaction at $260{ }^{\circ} \mathrm{C}$. All the $\mathrm{Bi}_{4} \mathrm{~V}_{2-x} \mathrm{Sb}_{x} \mathrm{O}_{11-y}$ catalysts showed higher $\mathrm{H}_{2} \mathrm{~S}$ conversion than $\mathrm{Bi}_{4} \mathrm{~V}_{2} \mathrm{O}_{11}(\mathrm{X}=58.1 \%)$ and $\mathrm{Sb}_{2} \mathrm{O}_{4}(\mathrm{X}=57.1 \%)$ did.

The $\mathrm{Bi}_{4} \mathrm{~V}_{2-x} \mathrm{Sb}_{x} \mathrm{O}_{11-y}$ catalysts of $\mathrm{x}=0.2$ showed the highest $\mathrm{H}_{2} \mathrm{~S}$ conversion. The increase of $\mathrm{x}$ resulted in an increase of ATS selec-

Table 3. Conversion of $\mathrm{H}_{2} \mathrm{~S}$ and product selectivity for $\mathrm{Bi}_{4} \mathrm{~V}_{2-x} \mathrm{Sb}_{x}$ $\mathrm{O}_{11-y}$ catalysts after $8 \mathrm{~h}$ of reaction at $260^{\circ} \mathrm{C}$

\begin{tabular}{lcccc}
\hline \hline Catalyst & $\mathrm{X}_{2} \mathrm{H}_{2} \mathrm{~S}(\%)$ & $\mathrm{S} \mathrm{SO}_{2}(\%)$ & $\mathrm{S}-\mathrm{S}(\%)$ & S-ATS $(\%)$ \\
\hline $\mathrm{Bi}_{4} \mathrm{~V}_{2} \mathrm{O}_{11}$ & 58.1 & 0 & 61.7 & 38.3 \\
$\mathrm{x}=0.2$ & 81.4 & 0 & 96.0 & 4.0 \\
$\mathrm{x}=0.5$ & 80.5 & 0 & 93.3 & 6.7 \\
$\mathrm{x}=1.0$ & 77.4 & 0 & 92.4 & 7.6 \\
$\mathrm{x}=1.7$ & 71.9 & 0 & 87.2 & 12.8 \\
$\mathrm{Sb}_{2} \mathrm{O}_{4}$ & 57.1 & 0 & 96.5 & 3.5 \\
\hline
\end{tabular}

Reaction condition: $\mathrm{H}_{2} \mathrm{~S} / \mathrm{O}_{2} / \mathrm{NH}_{3} / \mathrm{H}_{2} \mathrm{O} / \mathrm{He}=5 / 2.5 / 5 / 60 / 27.5$, GHSV= $12,000 \mathrm{~h}^{-1}$. 
tivity at the expense of the decrease of sulfur selectivity. It is known that the following elementary reactions occur in the Claus process in the absence of ammonia [Terorde et al., 1993].

$$
\begin{aligned}
& 2 \mathrm{H}_{2} \mathrm{~S}+\mathrm{O}_{2} \rightarrow{ }^{2}{ }_{n} \mathrm{~S}_{n}+2 \mathrm{H}_{2} \mathrm{O} \\
& { }^{1} / \mathrm{S}_{n}+\mathrm{O}_{2} \rightarrow \mathrm{SO}_{2} \\
& 2 \mathrm{H}_{2} \mathrm{~S}+3 \mathrm{O}_{2} \rightarrow 2 \mathrm{SO}_{2}+2 \mathrm{H}_{2} \mathrm{O} \\
& 2 \mathrm{H}_{2} \mathrm{~S}+\mathrm{SO}_{2} \rightarrow{ }^{3}{ }_{n} \mathrm{~S}_{n}+2 \mathrm{H}_{2} \mathrm{O}
\end{aligned}
$$

Previous works [Bai et al., 1992; Hartley and Matterson, 1975] reported that the reaction of $\mathrm{SO}_{2}$ with $\mathrm{NH}_{3}$ occurred to form ammonium sulfite, and it was accelerated by the presence of water vapor:

$$
\mathrm{SO}_{2}+2 \mathrm{NH}_{3}+\mathrm{H}_{2} \mathrm{O} \rightarrow\left(\mathrm{NH}_{4}\right)_{2} \mathrm{SO}_{3}
$$

Ammonium thiosulfate (ATS) is commercially produced by the reaction of ammonium sulfite with excess sulfur:

$$
\left(\mathrm{NH}_{4}\right)_{2} \mathrm{SO}_{3}+\mathrm{S} \rightarrow\left(\mathrm{NH}_{4}\right)_{2} \mathrm{~S}_{2} \mathrm{O}_{3}
$$

ATS can also be produced by the reaction of ammonium sulfide [Chang and McGaugh, 1988], ammonium sulfite, and $\mathrm{SO}_{2}$ :

$$
\begin{aligned}
& \mathrm{H}_{2} \mathrm{~S}+2 \mathrm{NH}_{3} \rightarrow\left(\mathrm{NH}_{4}\right)_{2} \mathrm{~S} \\
& \left(\mathrm{NH}_{4}\right)_{2} \mathrm{SO}_{3}+2\left(\mathrm{NH}_{4}\right)_{2} \mathrm{~S}+3 \mathrm{SO}_{2} \rightarrow 3\left(\mathrm{NH}_{4}\right)_{2} \mathrm{~S}_{2} \mathrm{O}_{3}
\end{aligned}
$$

Fig. 3 shows a typical temperature dependence of $\mathrm{H}_{2} \mathrm{~S}$ conversion for $\mathrm{Bi}_{4} \mathrm{~V}_{2-x} \mathrm{Sb}_{x} \mathrm{O}_{11-y}$ catalysts. The catalyst with $\mathrm{x}=0.2$ showed the highest $\mathrm{H}_{2} \mathrm{~S}$ conversion over the entire temperature ranges of 220$320^{\circ} \mathrm{C}$. The conversion increased up to $260^{\circ} \mathrm{C}$, then it decreased over this temperature. According to the estimated equilibrium calculations reported by Chun [1998], the equilibrium conversion of $\mathrm{H}_{2} \mathrm{~S}$ for the Claus process (Eqs. (1)-(4)) decreased with increasing reaction temperature [Park et al., 2002]. However, below $220^{\circ} \mathrm{C}$ (not shown in Fig. 3) $\mathrm{H}_{2} \mathrm{~S}$ conversion decreased abruptly because

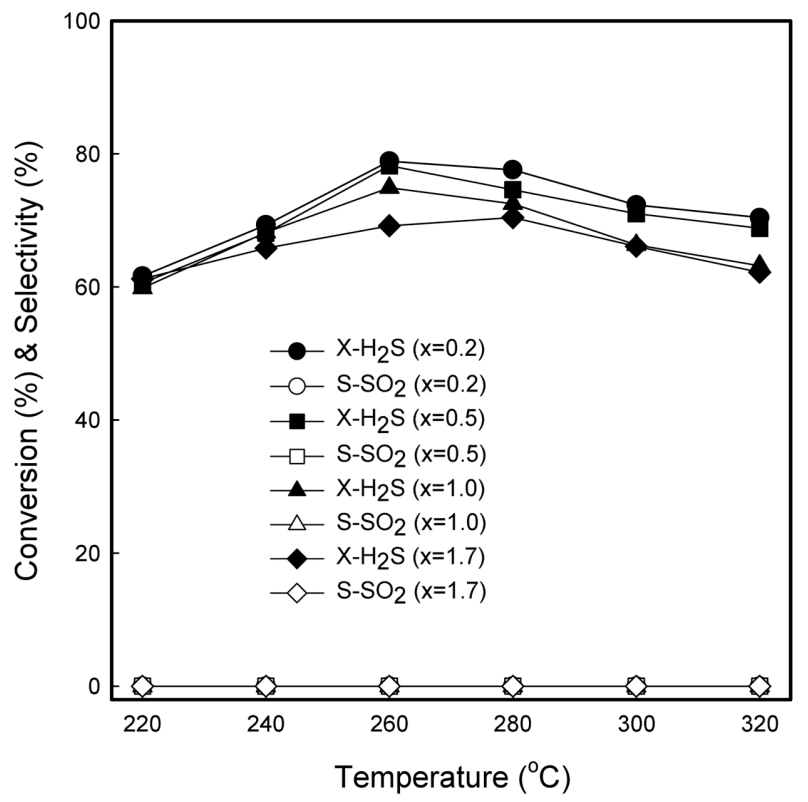

Fig. 3. Conversion of $\mathrm{H}_{2} \mathrm{~S}$ and selectivity to $\mathrm{SO}_{2}$ for $\mathrm{Bi}_{4} \mathrm{~V}_{2-x} \mathrm{Sb}_{x} \mathrm{O}_{11-y}$ catalysts at different temperatures $\left(\mathrm{H}_{2} \mathrm{~S} / \mathrm{O}_{2} / \mathrm{NH}_{3} / \mathrm{H}_{2} \mathrm{O} / \mathrm{He}=\right.$ $5 / 2.5 / 5 / 60 / 27.5$, GHSV $=12,000 \mathrm{~h}^{-1}$ ).

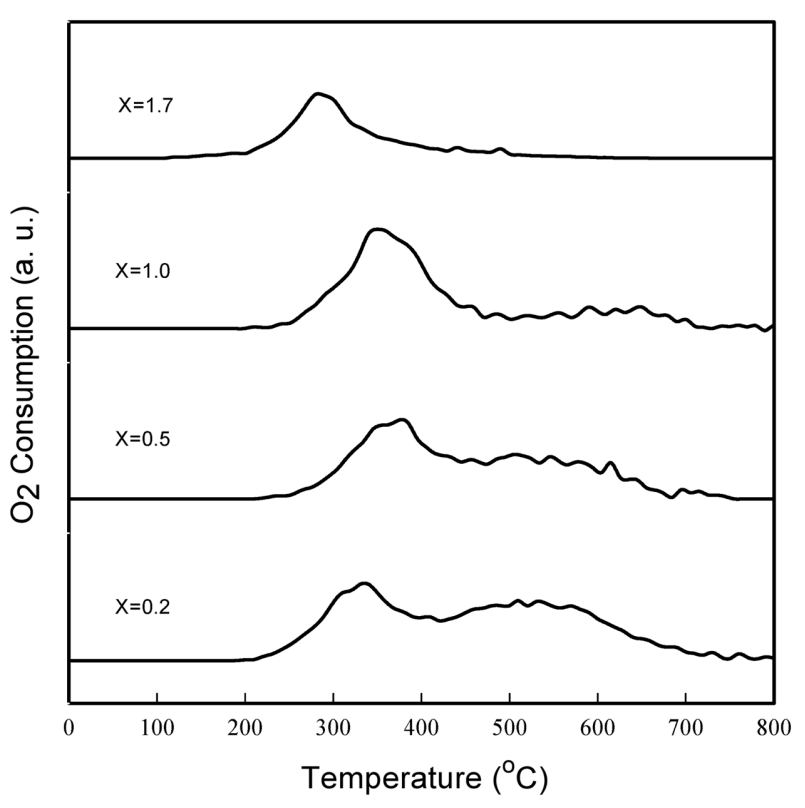

Fig. 4. TPO profiles of $\mathrm{Bi}_{4} \mathrm{~V}_{2-x} \mathrm{Sb}_{x} \mathrm{O}_{11-y}$ catalysts.

Table 4. Desorbed amount of $\mathrm{H}_{2}$ and $\mathrm{O}_{2}$ in TPR and TPO experiments

\begin{tabular}{ccc}
\hline \hline Catalysts $\left(\mathrm{Bi}_{4} \mathrm{~V}_{2-x} \mathrm{Sb}_{x} \mathrm{O}_{11-y}\right)$ & $\mathrm{H}_{2}(\mu \mathrm{mol} / \mathrm{g}$-cat $)$ & $\mathrm{O}_{2}(\mu \mathrm{mol} / \mathrm{g}$-cat $)$ \\
\hline $\mathrm{x}=0.2$ & 27.6 & 53.0 \\
$\mathrm{x}=0.5$ & 23.2 & 42.0 \\
$\mathrm{x}=1.0$ & 27.9 & 36.9 \\
$\mathrm{x}=1.7$ & 25.7 & 24.4 \\
\hline
\end{tabular}

of sulfur condensation on the surface of catalyst.

\section{Redox Behaviour of Catalyst}

To identify the highest activity for the catalyst with $\mathrm{x}=0.2$, a comparative temperature-programmed reduction (TPR) followed by temperature-programmed oxidation (TPO) were carried out for $\mathrm{Bi}_{4}$ $\mathrm{V}_{2-x} \mathrm{Sb}_{x} \mathrm{O}_{11-y}$. The reducibility of the catalysts was first measured by using TPR method with hydrogen as a reductant, and the TPO results are shown in Fig. 4. The amount of hydrogen and oxygen consumed is summarized in Table 4. In the TPO experiment, the catalyst with $\mathrm{x}=0.2$ showed the best reoxidation property. The amount of oxygen consumption decreased with increasing $\mathrm{x}$, which is in accordance with the order of $\mathrm{H}_{2} \mathrm{~S}$ conversion with the variation of $\mathrm{x}$. However, the amounts of hydrogen consumption were not so different from others.

The oxidation state of vanadium in $\mathrm{Bi}_{4} \mathrm{~V}_{2-x} \mathrm{Sb}_{x} \mathrm{O}_{11-y}$, was also studied by XPS. Fig. 5 shows XPS spectra of V $2 p_{3 / 2}$ for these catalysts before and after $8 \mathrm{~h}$ of reaction at $260{ }^{\circ} \mathrm{C}$ with the standard reactant mixture and GHSV of $12,000 \mathrm{~h}^{-1}$. The standard XPS peaks of $\mathrm{V}$ $2 \mathrm{p}_{3 / 2}$ for $\mathrm{V}^{5+}$ and $\mathrm{V}^{4+}$ are located 516.9 and $515.6 \mathrm{eV}$, respectively. After the reaction, the XPS spectra were broadened and shifted to lower binding energy. It means that some of the catalyst surface having $\mathrm{V}^{5+}$ state is reduced to $\mathrm{V}^{4+}$ after the reaction. The full-width half-maximum (FWHM) value for the fresh catalyst with $\mathrm{x}=0.2$ was $2.333 \mathrm{eV}$, and that for the used catalyst was $2.381 \mathrm{eV}$. It corresponds to $2.1 \%$ increase in FWMH after the reaction. However, the catalyst with $\mathrm{x}=0.5$ showed $1.571 \mathrm{eV}$ for the fresh catalyst and 


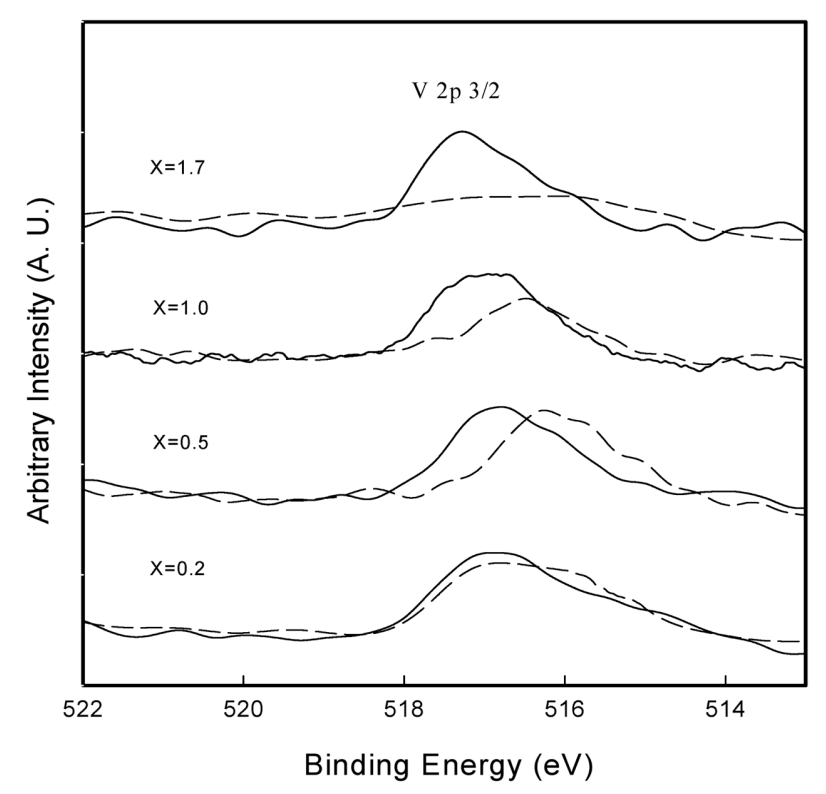

Fig. 5. XPS analyses of $\mathrm{V} 2 \mathrm{p}_{3 / 2}$ for $\mathrm{Bi}_{4} \mathrm{~V}_{2-x} \mathrm{Sb}_{x} \mathrm{O}_{11-y}$ catalysts before (solid line) and after (dashed line) the reaction: Reaction condition $\left(\mathrm{H}_{2} \mathrm{~S} / \mathrm{O}_{2} / \mathrm{NH}_{3} / \mathrm{H}_{2} \mathrm{O} / \mathrm{He}=5 / 2.5 / 5 / 60 / 27.5, \mathrm{GHSV}=\right.$ $\left.12,000 \mathrm{~h}^{-1}\right)$.

$1.714 \mathrm{eV}$ for the used one, 9.1\% increase in FWMH. Therefore, after the reaction the catalyst with $\mathrm{x}=0.2$ shows less reduction of vanadium phase than that of $x=0.5$. The degree of percentage increase in FWMH, implying the degree of reduction after reaction, increased with the increase of $x$. This can support the highest reoxidation ability of the catalyst with $\mathrm{x}=0.2$.

\section{CONCLUSION}

The selective oxidation of hydrogen sulfide in the presence of excess water and ammonia was investigated using $\mathrm{Bi}_{4} \mathrm{~V}_{2-x} \mathrm{Sb}_{x} \mathrm{O}_{11-y}$ catalysts. Hydrogen sulfide was successfully converted into harmless ammonium thiosulfate and elemental sulfur without considerable emission of sulfur dioxide. The mixed oxide catalyst with $\mathrm{x}=$ 0.2 showed the highest conversion of $\mathrm{H}_{2} \mathrm{~S}$. The TPO and XPS results supported the importance of reoxidation ability of this catalyst for the good conversion of $\mathrm{H}_{2} \mathrm{~S}$.

\section{ACKNOWLEDGMENT}

This work was supported by the Korea Science and Engineering Foundation (R05-2003-000-10050-0), and Brain Korea 21 and Brain Busan 21 program.

\section{REFERENCES}

Aghabozorg, H. R., Flavell, W. R. and Sakakini, B. H., "Catalytic Properties of $\mathrm{Bi}_{4} \mathrm{~V}_{2-x} \mathrm{Sb}_{x} \mathrm{O}_{11-\mu}$ in Methanol Oxidation,' J. Catal., 167, 164 (1997).

Bai, H., Biswas, P. and Keener, T. C., "Particle Formation by $\mathrm{NH}_{3}-\mathrm{SO}_{2}$ Reactions at Trace Water Conditions,' Ind. Eng. Chem. Res., 31, 88 (1992).
Benito, J. F., "Procedimiento de Fabricacion de Tiosulfato Amonico," ES Patent No. 547,563 (1986).

Chang, D. and McGaugh, "Continuous Process for Scrubbing Hydrogen Sulfide from Gas Streams to Produce Elemental Sulfur,' US Patent 4,765,649 (1988).

Cho, Y. G., Hwang, B. H., Park, D. W., Woo, H. C. and Chung, J. S., "Phase Cooperation of $\mathrm{V}_{2} \mathrm{O}_{5}$ and $\mathrm{Bi}_{2} \mathrm{O}_{3}$ in the Selective Oxidation of $\mathrm{H}_{2} \mathrm{~S}$ Containing Ammonia and Water,', Korean J. Chem. Eng., 19, 611 (2002).

Chun, S. W., Jang, J. Y., Park, D. W., Woo, H. C. and Chung, J. S., “'Selective Oxidation of $\mathrm{H}_{2} \mathrm{~S}$ in the Presence of Ammonia and Water Using $\mathrm{Co}_{3} \mathrm{O}_{4} / \mathrm{SiO}_{2}$ Catalyst,' Korean J. Chem. Eng., 14, 216 (1997).

Chun, S. W., "Removal of Hydrogen Sulfide by Selective Catalytic Oxidation,' Ph. D. Thesis, Pusan National University, Busan, Korea (1998).

Gaigneaux, E. M., Englebert, F. and Ruiz, P., "A Rational Strategy to Design Performant Multiphasic Oxide Catalysts Based on the Cooperation between Phases via Spillover Oxygen : The Bi-V-Sb-O System,' Stud. Surf. Sci. Catal., 138, 145 (2001).

Goar, B. G., "Todays Claus Tail Gas Clean-Up Processes,' Oil \& Gas J., 25, 96 (1975).

Hartley, E. M. and Matterson, M. J., "Sulfur Dioxide Reaction with Ammonia in Humid Air,' Ind Eng. Chem. Fundam., 14, 67 (1975).

Kettner, R. and Liermann, N., "New Claus Tail Gas Process Proved in German Operation,' Oil \& Gas J., Jan. 11, 63 (1988).

Kettner, R. and Liermann, N., "Processes for the Reduction of the Sulfur Content in a Gaseous Stream,' Europe Patent 78,690 (1983), to Mobil Oil Corporation.

Kim, B. K., Hwang, B. H., Lee, H. S., Woo, H. C. and Park, D. W., "Selective Oxidation of $\mathrm{H}_{2} \mathrm{~S}$ to Ammonium Thiosulfate and Elemental Sulfur Using Mixture of $\mathrm{V}-\mathrm{Bi}-\mathrm{O}$ and $\mathrm{Sb}_{2} \mathrm{O}_{4}$, Korean J. Chem. Eng., 21, 104 (2004).

Lell, R., 'Sulphur Recovery by the Claus and Maxisulf Processes,' Sulphur, 178, 29 (1985).

Li, K. T., Huang, M. Y. and Cheng, W. D., "Vanadium-Based Mixed Oxide catalysts for Selective Oxidation of Hydrogen Sulfide to Sulfur,' Ind. Eng. Chem. Res., 35, 621 (1996).

$\mathrm{Li}, \mathrm{K}$. T. and Shyu, N. S., "Catalytic Oxidation of $\mathrm{H}_{2} \mathrm{~S}$ to $\mathrm{S}$ on Vanadium Antimonate,' Ind. Eng. Chem. Res., 36, 1480 (1997).

Park, D. W., Chun, S. W., Jang, J. Y., Kim, H. S., Woo, H. C. and Chung, J. S., "Selective Removal of $\mathrm{H}_{2} \mathrm{~S}$ from Coke Oven Gas," Catal. Today, 44, 73 (1998).

Park, D. W., Chun, S. W., Kim, H. S., Woo, H. C. and Chung, J. S., 'Recovery of $\mathrm{H}_{2} \mathrm{~S}$ in Coke Oven Gas as Elemental Sulfur and Ammonium Sulfate by Catalytic Oxidation," Stud. Surf. Sci. Catal., 121, 457 (1999).

Park, D. W., Park, B. K., Park, D. K. and Woo, H. C., "Vanadium-antimony Mixed Oxide Catalysts for the Selective Oxidation of $\mathrm{H}_{2} \mathrm{~S}$ Containing Excess Water and Ammonia,' Appl. Catal. A. Gen., 223, 215 (2002).

Pi, J. H., Lee, D. H., Lee, J. D., Jun, J. H., Park, N. K., Ryu, S. O. and Lee, T. J., "The Study on the Selective Oxidation of $\mathrm{H}_{2} \mathrm{~S}$ over Mixture $\mathrm{NaX}_{-}-\mathrm{WO}_{3}$ Catalysts,' Korean J. Chem. Eng., 21, 126 (2004).

Pomonis, P. J. and Vickerman, J. C., "Methanol Oxidation over Vanadium-containing Model Oxide Catalysts. Influence of Charge-transfer Effects on Selectivity,' Faraday Discuss. Chem. Soc., 72, 247 (1981). 
Sammes, N. M., Tompsett, G. A., Nafe, H. and Aldinger, F., "Bismuth Based Oxide Electrolytes-Structure and Ionic Conductivity,' J. Euro. Ceram. Soc., 19, 1801 (1999).

Shin, M. Y., Park, D. W. and Chung, J. S., "Vanadium-Containing Catalysts for the Selective Oxidation of $\mathrm{H}_{2} \mathrm{~S}$ to Elemental Sulfur in the Presence of Excess Water,' Catal. Today, 63, 405 (2000).

Terode, R. J. A. M., van den Brink, P. J., Visser, L. M., Dillen, A. J. and Geus, J. W., "Selective Oxidation of Hydrogen Sulfide to Elemental Sulfur Using Iron Oxide Catalysts on Various Supports,' Catal. Today, 17, 217 (1993). van den Brink, P. J. and Geus, J. W., "Selective Oxidation of Hydrogen Sulfide on a Sodium Promoted Iron Oxide on Silica Catalyst,' US Patent 5,352,422 (1994), to VEG-Gasinstituut N.V. and Comprimo B.V.

van Nisselrooy, P. F. M. T. and Lagas, J. A., "SUPERCLAUS Reduces Sulfur Dioxide Emission by the Use of a New Selective Oxidation Catalyst,' Catal. Today, 16, 263 (1993).

Zey, A., White, S. and Johnson, D., "The ATS Claus Tail Gas Cleanup Process,' Chem. Eng. Prog., 76, 10 (1980). 